\title{
Incidence of arthropods and phytotechnical characteristics of lisianthus under different greenhouse conditions
}

\author{
Marcia Yamada*, Simone Mundstock Jahnke, Gilmar Schäfer
}

\begin{abstract}
The use of color shading meshes is presented as a new technological approach to manage flowers and ornamental plants. Eustoma grandiflorum (Raf.) Shinners is a flower that excites interest of producers and consumers. However, there is little technical and scientific information on its production and management. We evaluated the incidence of arthropods and phytotechnical characteristics in two cultivars of cut lisianthus, under the influence of different color shading meshes in commercial greenhouse. The experiments were conducted in the company Floricultura Florist, Dois Irmãos-RS, Brazil. The experiment took place from August to December 2012 and tested the influence of shading meshes with different colors (gray, red, black, and blue) on two varieties of cut lisianthus (Mariage and Bolero White). In each treatment, the phytotechnical characteristics of the plants assessed and arthropod samples were collected. Red mesh produced the best results, and blue, the worst. Nine orders of arthropods from 24 families with different habits were observed. Diptera was the most abundant. The shading screens did not influence the number of arthropods in plants.
\end{abstract}

Keywords: Colored shading screens, lisianthus, greenhouse, natural enemies, pests.

\section{Resumo}

Incidência de artrópodes e características fitotécnicas de lisiantos cultivados em casa de vegetação com diferentes condições

A utilização de malhas de sombreamento coloridas apresenta-se como uma nova abordagem tecnológica no manejo de flores e plantas ornamentais. Eustoma grandiflorum (Raf.) Shinners é uma flor que desperta interesse de produtores e consumidores, embora existam poucas informações técnicas e científicas sobre produção e manejo. Objetivou-se avaliar as características fitotécnicas e a incidência de artrópodes em dois cultivares de lisianto de corte, sob a influência de malhas de sombreamento coloridas em cultivo protegido comercial. O experimento foi conduzido na Floricultura Florist Ltda., em Dois Irmãos, RS, de agosto a dezembro de 2012 e testou a influência das malhas com colorações distintas (cinza, vermelha, preta e azul) sobre os cultivares Mariage e Bolero White. As malhas vermelhas obtiveram os melhores resultados e em azul, os piores. Foram registradas nove ordens de artrópodes de 24 famílias com diferentes hábitos, sendo Diptera a mais abundante. As malhas de sombreamento não influenciaram no número médio de artrópodes nas plantas.

Palavras-chave: Ambiente protegido, malhas fotosseletoras, manejo cultural, inimigos naturais, pragas.

\section{Introduction}

Floriculture is the most dynamic segment of horticulture and an inducer of changes, with important reflections on the commercial cultivation of other horticultural plants (Junqueira and Peetz, 2008). Because of its great capacity to generate income, floriculture is very attractive to small and large farmers (Duval, 2014). In ornamental production, the occurrence of pests and diseases remains a limiting factor, since few registered chemicals are marketed specifically for them (AGROFIT, 2018), and studies on alternative management and biological control are scarce.
Among the cut flowers that have stimulated interest, both by producers and consumers, is the lisianthus (Eustoma grandiflorum (Raf.) Shinners, which presents interesting planting characteristics for the market, such as buds with good durability, variety of colors, and the possibility to be cultivated throughout the year (Mathias, 2011). Recently some works have been carried out on the propagation of lisianthus (Sotomayor et al, 2016); however, there is little technical and scientific information about its production, management, and associated pests. Thus, producers are led to use techniques that may not exploit the full potential of the crop (Backes et al., 2008). 
The use of shading mesh and color photos during the development of ornamental flowers and plants is presented as a new technological approach to manage quality and quantity of light incident on plant breeding characteristics. There is a gap in knowledge about the effect of color meshes in the presence of insects and diseases in flowers. Knowing this influence, this technique may be complementary to integrated pest management (IPM) in protected cultivation.

Therefore, the objective of this work was to evaluate the phytotechnical characteristics and to perform the arthropod survey in the different phases of development of two cultivars of cut lisianthus, under the influence of color shading meshes in protected cultivation in a conventional production system.

\section{Material and Methods}

The study was carried out at Floriculture Florist Ltda in

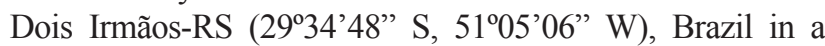
greenhouse area with galvanized steel structure, arch ceiling, and $4.5 \mathrm{~m}$ ceiling height. The tunnels are located longitudinally in a north-south direction covered by a transparent plastic canvas of low density polyethylene (LDPE) with 100 microns thick. It has side curtains for handling the air circulation and black side meshes $(50 \%)$. The total area of $2,180 \mathrm{~m}^{2}$ was used only for lisianthus cultivation.

The experiment was performed from August (31st week of the year) to December 2012 (49th week). Two flowerbeds ( $25 \mathrm{~m}$ long by one meter wide) were delineated with two cultivars, F1 Mariage ${ }^{\circledR}$ and F1 Bolero White ${ }^{\circledR}$ (Mariage and Bolero White), both with white flowers. The Bolero White is early blossoming and less susceptible to rosing (non-issuance of the flower stem), with sturdy stems and good post-harvest preservation, Mariage has between intermediate to large size flowers with slower flowering (Miyoshi \& CO., 2012).

The seedlings, from São Paulo, were transplanted to the flowerbeds (01/08/2012), directly in the soil, approximately 60 days after germination, at a density of 75 plants $/ \mathrm{m}^{2}$. On the flowerbeds $\left(100 \mathrm{~m}^{2}\right)$, at $1.80 \mathrm{~m}$ high, four types of colored meshes $\left(176.8 \mathrm{~m}^{2}\right)$ were placed which had shading between $30 \%$ and $38 \%$. Three meshes were supplied by SOL Pack (FreshNet ${ }^{\circledR}$ blue, 38\%; Agritela ${ }^{\circledR}$ black, 35\%; and Agritela $^{\circledR}$ FTS red, 35\%) and one purchased which was made by the producer of Polysack (Chromatinet ${ }^{\circledR}$ gray, $30 \%$ ). During the experiment, the meshes were extended according to the temperature management adopted by the producer, when the temperature outside the protected crop exceeded $25{ }^{\circ} \mathrm{C}$. For the first 11 weeks, shading meshes were used approximately $47 \%$ of days. From the second half of October, when the plants were in the reproductive phase, until the cutting period, the use of meshes was constant.

The variables temperature (maximum and minimum) and relative humidity (maximum and minimum) were measured weekly using digital thermo-hygrometers installed in wooden stakes approximately $60 \mathrm{~cm}$ above the ground in the center of each area with a different color mesh.
For phytosanitary management, the producer weekly applied preventive pest control with different active ingredients (formetanate hydrochloride, cyromazine, spinosad, and imidacloprid). The fungicide applications (pyrimethanil, azoxystrobin, diphenoconazole, and thiophanate-methyl) were also carried out in a preventive way to control botrytis, powdery mildew, and mildew.

The experimental design was a completely randomized blocks (four replications) in a subdivided plot scheme. To collect the data of the phytotechnical characteristics in each plot, nine central plants were used, of which the height of the stem, the number of leaves of the main stem, and the quantity of flowers per plant were evaluated.

At flower harvesting time (125 days after transplanting (DAT) - 03/12/2012), 16 whole plants of each treatment were collected and taken to the laboratory. The height and diameter of the main and secondary stems, flowers open per plant, total dry mass, and leaf area were recorded. The leaf area was determined using a LI-COR benchmark, model LI 3000. To measure the dry matter mass, all parts of the plant (roots, stems, leaves, buds, and flowers) were put into paper bag and weighed in an electronic scale to obtain the wet mass and placed in an oven at $70{ }^{\circ} \mathrm{C}$ to dry to a constant weight.

The presence of damage caused by diseases (fungal symptoms: grayish-brown stains of varying sizes and shapes on leaves), phytophagous (gallstones), and mechanical (damaged leaves and flowers) were observed according to commercial standards of lisianthus by Ibraflor, established by the Veiling Holambra Cooperative (2012). In addition to the damages, according to the Ibraflor standard, the marketing standard was also classified (height and thickness of the floral stem, flowers open per packet, and average pack weight).

Arthropod samplings were performed biweekly from 25 DAT to 115 DAT, for a total of seven sampling. Each treatment (cultivar $\mathrm{x}$ mesh) was divided into three $1.0 \mathrm{~m}^{2}$ plots, covering the eight treatments. All plants (approximately 75) of each plot were observed for three minutes by two samplers. The arthropods observed were collected manually with tweezers and small entomological net, totaling $144 \mathrm{~min}$ of sample effort at each occasion. The samples were placed in plastic microtubes $(2 \mathrm{~mL})$ with $70 \%$ alcohol for later screening in the Laboratory of Biological Control of Insects (CBLAB) of UFRGS. Arthropods were identified by Order and Family using dichotomous keys, and generic or specific identifications were made by specialists. The identified arthropods are in a reference collection in the CBLAB. The relative frequency (f), abundance (N), and species richness (S) were established for each cultivar.

The mean data of the phytotechnical characteristics and arthropod collected in the different treatments and between cultivars were analyzed for normality by the Shapiro-Wilk test and submitted to analysis of variance, the means being compared by ANOVA, followed by the Tukey test, or by Kruskall Wallis followed by Dunn test with a significance level of $5 \%$ by the statistical program ASSISTAT, version 7.7 (Silva and Azevedo, 2016). 


\section{Results and Discussion}

\section{Evaluation of the phytotechnical characteristics}

Both lisianthus cultivars began to flower at 95 DAT, which is in agreement with other studies that indicate a premature flowering, beginning at 98 days, on long days, in which case the plants are shorter compared to those grown on short days and lower average temperature (Harbaugh, 1995). At the time of flower cut, there was no significant difference in plant height among the cultivars studied, but there was a difference between the color shading meshes (Table 1). Plants under the red shading mesh grew, on average, significantly more than under gray and black, which were higher than the blue color (Table 1). Ovadia et al. (2009) also found significantly higher values in the lisianthus grown under yellow and red shading meshes compared to those in black and blue, although those authors worked with the cultivars Mirage Pastel, Flamenco Purple, and Flamenco Red. The results may have been influenced by the management of the shading mesh, since these were used constantly from the second fortnight of October, a period that coincided with the reproductive phase of the plants. Even the plants that grew under a blue color mesh, met the height required by Ibraflor quality standards, which is 40 to $70 \mathrm{~cm}$ (Cooperativa Veiling Holambra, 2012).

Table 1. Effect of different shading meshes on mean stem height, mean flower numbers, leaves, secondary stems, and stem thickness in two cut lisianthus cultivars.

\begin{tabular}{|c|c|c|c|c|c|}
\hline \begin{tabular}{c} 
Treatment \\
\hline Cultivate / Meshes
\end{tabular} & Height (cm) & Flowers & Leaves & $\begin{array}{c}\text { Thickness of rod } \\
(\mathbf{m m})\end{array}$ \\
\hline Mariage & $80.30 \mathrm{~ns}$ & $7.28 \mathrm{~b}$ & $18.88 \mathrm{~ns}$ & $6.43 \mathrm{~ns}$ \\
\hline Bolero White & 81.61 & $8.28 \mathrm{a}$ & 19.41 & $3.88 \mathrm{~b}$ & 6.21 \\
\hline C.V. (\%) & 2.26 & 10.9 & 5.35 & 6.26 \\
\hline Red & $85.19 \mathrm{a}$ & $8.91 \mathrm{a}$ & $19.63 \mathrm{ab}$ & $6.75 \mathrm{~ns}$ \\
\hline Gray & $80.97 \mathrm{~b}$ & $8.5 \mathrm{a}$ & $19.75 \mathrm{a}$ & 4.03 & $6.57 \mathrm{ab}$ \\
\hline Black & $81.09 \mathrm{~b}$ & $7.5 \mathrm{ab}$ & $18.63 \mathrm{bc}$ & 4.34 & $5.9 \mathrm{c}$ \\
\hline Blue & $76.56 \mathrm{c}$ & $6.22 \mathrm{~b}$ & $18.56 \mathrm{c}$ & 3.90 & $6.08 \mathrm{bc}$ \\
\hline C.V. (\%) & 2.77 & 18.89 & 3.75 & 14.68 & 6.32 \\
\hline
\end{tabular}

* Means followed by distinct letters in the column differ from each other by the Tukey test, at the level of 5\% error probability. ns $=$ not significant. C.V $=$ coefficient of variation.

The precocity of the Bolero White cultivar was evidenced at the time of cutting, when it presented more open flowers than Mariage. The blue shading screen interfered in the number of open flowers, with lower average than the gray and red screens (Table 1). This can be explained because receiving the far red wavelength in quantity causes the plant to change its metabolism to compete by increasing the internode or blooming in advance. Even so, for commercialization, the number of open flowers on average for the two cultivars was six times higher than the standard required by Ibraflor (Cooperativa Veiling Holambra, 2012).

The number of leaves was not significantly different between the cultivars. This variable was higher under the red and gray shading mesh, and lower under the blue mesh (Table 1). Similarly, the mean stem thickness was not different between cultivars, but the plants under the red and gray mesh had a greater thickness than the black mesh (Table 1). Alves et al. (2015) found average values of stem diameter similar to this study (6.7 to $5.2 \mathrm{~mm}$ ) and said that this provided higher weight, lift, and vase life of the cut flower for the studied varieties. Roni et al. (2017) examined the effects of blue, red, and white LEDs on the photosynthetic performance of Eustoma and related anatomical features. They observed that the blue LEDs were associated with thicker leaf abaxial, different from our work. Nevertheless, the average thickness of the stems also met the minimum thickness $(4 \mathrm{~mm})$ required by Ibraflor (Cooperativa Veiling Holambra, 2012). The number of leaves and secondary stems are important to increase fresh weight, since their commercialization is based also on their fresh weight (Cooperativa Veiling Holambra, 2012). 
The average dry matter yield was $53.45 \mathrm{~g}$ for the cultivar Mariage and $50.23 \mathrm{~g}$ for Bolero White (Table 2). Values were higher than those found by Camargo et al. (2004) for cultivar Echo (28.4 g). The accumulation of total dry mass was higher under the red and gray shading meshes and lower in the blue; the black presented intermediate values (Table 2). For the weight of leaves, flowers, stems and for leaf area, the red shade mesh showed significantly higher results than under other mesh stains (Table 2).

Table 2. Amount of total dry mass of roots, leaves, buds, flowers, and stems, as well as leaf area of two cultivars of cut lisianthus (Mariage and Bolero White), kept under shading meshes (red, gray, black, and blue).

\begin{tabular}{|c|c|c|c|c|c|c|c|}
\hline $\begin{array}{c}\text { Treatment } \\
\text { Cultivate / } \\
\text { Meshes }\end{array}$ & $\begin{array}{l}\text { Total dry } \\
\text { mass } \\
\text { (g) }\end{array}$ & $\begin{array}{l}\text { Roots } \\
\text { (g) }\end{array}$ & $\begin{array}{c}\text { Leaves } \\
\text { (g) }\end{array}$ & $\begin{array}{c}\text { Buds } \\
\text { (g) }\end{array}$ & $\begin{array}{c}\text { Flowers } \\
\text { (g) }\end{array}$ & $\begin{array}{l}\text { Stems } \\
(\mathrm{g})\end{array}$ & $\begin{array}{l}\text { Leaf } \\
\text { area } \\
\left(\mathrm{cm}^{2}\right)\end{array}$ \\
\hline Mariage & $53.45 \mathrm{~ns}$ & $3.28 \mathrm{a}^{*}$ & $11.13 \mathrm{~ns}$ & $4.18 \mathrm{~ns}$ & $12.38 \mathrm{~ns}$ & $1.49 \mathrm{a}$ & $2303.19 \mathrm{~ns}$ \\
\hline $\begin{array}{l}\text { Bolero } \\
\text { White }\end{array}$ & 50.23 & $2.85 \mathrm{~b}$ & 10.62 & 3.63 & 13.19 & $19.94 \mathrm{~b}$ & 2132.19 \\
\hline C.V. (\%) & 10.98 & 11.89 & 12.35 & 24.2 & 13.5 & 12.94 & 12.31 \\
\hline Red & $60.60 \mathrm{a}$ & $3.50 \mathrm{a}$ & $12.82 \mathrm{a}$ & $4.57 \mathrm{~ns}$ & $14.47 \mathrm{a}$ & $25.25 \mathrm{a}$ & 2700.63 a \\
\hline Gray & $53.66 \mathrm{ab}$ & $3.16 \mathrm{a}$ & $10.82 \mathrm{~b}$ & 3.40 & $14.71 \mathrm{a}$ & $21.57 \mathrm{~b}$ & $2161.00 \mathrm{~b}$ \\
\hline Black & $50.95 \mathrm{~b}$ & $3.12 \mathrm{a}$ & $10.72 \mathrm{~b}$ & 4.08 & $12.20 \mathrm{ab}$ & $20.82 b c$ & $2125.13 b$ \\
\hline Blue & $42.16 \mathrm{c}$ & $2.48 \mathrm{~b}$ & $9.15 \mathrm{~b}$ & 3.57 & $9.75 \mathrm{~b}$ & $17.21 \mathrm{c}$ & $1884.00 \mathrm{~b}$ \\
\hline C.V. $(\%)$ & 11.03 & 13.73 & 12.55 & 25.93 & 15.67 & 12.26 & 11.28 \\
\hline
\end{tabular}

* Means followed by distinct letters in the column differ from each other by the Tukey test, at the level of $5 \%$ error probability. ns $=$ not significant. C.V $=$ coefficient of variation.

The black and blue meshes caused lower performance in the weight of flowers. Melo and Alvarenga (2009) observed similar results to the present study in vinca plants (Catharanthus roseus), with total dry matter increase and leaf area under red mesh compared to blue and black meshes and treatment in full sun. The authors attributed this increment of total dry mass to the lower red/far-red ratio, provided by the red shading mesh. This difference in the ratio between the red and far-red supplied to a plant can cause morphological differentiations in the leaf limbus (Kasperbauer, 1994). Blue light, whose radiation is in the range of $480 \mathrm{~nm}$, promotes a decrease in cell elongation, compaction, and shortening of internodes in plants (Helson, 1965; Murata et al., 1997), which may have contributed to the lower accumulation of total dry mass under blue shading mesh in this work.

The weight of buds, however, did not differ between meshes. Considering the cultivars, Mariage presented greater weight of roots and stems, while the other parameters did not differ (Table 2).

\section{Diversity and density of arthropods}

The mean number of arthropods collected between dates varied related to DAT (Table 3 ). The low number of insects collected at 55 DAT can be explained by an application of insecticide made one day before sampling (farmer personal communication). In the reproductive period of the plants, the average catch was lower. In general, the richness and abundance of insects is amplified with the advancement of the plant cycle in open environments and are higher in the flowering period (Frank et al., 2012), which, in the greenhouse, with the application of insecticides, did not occur in this study. The application of agrochemicals occurred weekly during the cultivation, uniformly, in all treatments. Despite the great amount of products applied with different active principles (farmer personal communication), several groups of arthropods were still observed. 
Table 3. Mean ( \pm standard error) of arthropods collected in cultivars of cut lisianthus, Mariage and Bolero White, on seven collection dates, from August to December 2012 and average number ( \pm standard error) of arthropods collected per treatment (cultivar x shading meshes)

\begin{tabular}{|c|c|c|c|c|}
\hline Days after transplantation & \multicolumn{3}{|c|}{ Cultivar } \\
\hline & & Mariage & Bolero White & Total \\
\hline $25(25 / 08 / 12)$ & & $6.50 \pm 1.93 \mathrm{abc} *$ & $7.17 \pm 1.94 \mathrm{ab}$ & $6.84 \pm 1.83 \mathrm{bc}$ \\
\hline $40(09 / 09 / 12)$ & Vegetative period & $15.25 \pm 1.50 \mathrm{c}$ & $10.08 \pm 1.85 \mathrm{~b}$ & $12.67 \pm 3.17 \mathrm{c}$ \\
\hline $55(24 / 09 / 12)$ & & $5.75 \pm 0.32 \mathrm{abc}$ & $5.42 \pm 0.57 \mathrm{ab}$ & $5.58 \pm 0.46 \mathrm{abc}$ \\
\hline $70(10 / 10 / 12)$ & & $9.42 \pm 1.20 \mathrm{bc}$ & $11.92 \pm 5.13 \mathrm{~b}$ & $10.67 \pm 3.70 \mathrm{c}$ \\
\hline $85(25 / 10 / 12)$ & & $3.59 \pm 0.74 \mathrm{abc}$ & $2.17 \pm 1.17 \mathrm{ab}$ & $2.87 \pm 1.20 \mathrm{ab}$ \\
\hline $100(09 / 11 / 12)$ & Reproductive period & $1.75 \pm 0.32 \mathrm{ab}$ & $1.25 \pm 0.69 \mathrm{a}$ & $1.50 \pm 0.56 \mathrm{ab}$ \\
\hline $115(22 / 11 / 12)$ & & $0.83 \pm 0.64 \mathrm{a}$ & $1.33 \pm 0.72 \mathrm{a}$ & $1.08 \pm 0.69 \mathrm{a}$ \\
\hline Meshes & & & & \\
\hline Red & & $6.52 \pm 1.88 \mathrm{aA}$ & $5.67 \pm 1.53 \mathrm{abA}$ & - \\
\hline Gray & & $6.38 \pm 1.98 \mathrm{aA}$ & $4.28 \pm 1.06 \mathrm{bA}$ & - \\
\hline Black & & $5.62 \pm 1.80 \mathrm{aA}$ & $7.33 \pm 2.47 \mathrm{aA}$ & - \\
\hline
\end{tabular}

* Means followed by different lowercase letters, in the column, and different capital letters, in the row differ from each other at the $5 \%$ level of significance, by the Kruskal-Wallis test.

The highest number of arthropods caught in the Mariage cultivar occurred only on the 40 DAT (Table 3). As management as identical, genotypic differences could perhaps explain the greater occurrence of arthropods in one of them, as reported by McArt et al. (2012) for different primrose genotypes (Oenothera biennis L.)

The shading meshes did not influence the number of arthropods collected between the cultivars. However, in the cultivar Bolero White, they interfered in the average number of the arthropods collected under different shading meshes (Table 3 ). The highest arthropod average was collected in the Bolero White cultivar under black shading and the lowest under the gray shading (Table 3). Similarly, in a study specifically evaluating whiteflies, Shahak et al. (2008) found two to three times more insects under black than yellow shading. Harpaz (1982) evaluated the presence of aphids under different colored meshes and found that red did not differ from black mesh, whereas white and pearl significantly reduced both aphid infestation and the incidence of PVY and CMV (Harpaz 1982; Shahak et al., 2008). The authors consider that the reflection of sunlight repelled the presence of aphids. These differences, however, were not clearly found in our work, perhaps because the meshes were not extended on the flower beds the entire time.

The abundance and richness of arthropod species in the Mariage variety was 532 individuals, and 29 morphospecies were identified, belonging to 18 Families and 8 Orders. While in Bolero White, 480 individuals were found, with 25 morphotypes consisting of 19 Families and 8 Orders.

Of the arthropod orders collected, six were of the Insecta class, one of Diplopoda (millipede), one of Arachnida (spiders and mites), and another of Collembola (springtail) (Table 4). These arthropods had different feeding habits, distributed among phytophagous (37.5\%), entomophagous (predators and parasitoids) $(37.5 \%)$, and others $(25 \%)$ whose eating habits were not directly import (Table 4). 
Table 4. Class, order, family, food habit, number of individuals, relative frequency, and constancy of arthropods collected in the culture of cut lisianthus, under protected environment, under shading mesh, from August to December 2012.

\begin{tabular}{|c|c|c|c|c|c|c|c|c|c|}
\hline \multirow[t]{2}{*}{ Class } & \multirow[t]{2}{*}{ Order } & \multirow[t]{2}{*}{ Family } & \multirow{2}{*}{$\begin{array}{l}\text { Food } \\
\text { habit }\end{array}$} & \multicolumn{3}{|c|}{ Mariage } & \multicolumn{3}{|c|}{ Bolero White } \\
\hline & & & & $\mathbf{N}$ & $F(\%)$ & $\mathrm{C}$ & $\mathbf{N}$ & $F(\%)$ & C \\
\hline \multirow[t]{2}{*}{ ARACHNIDA } & MESOSTIGMATA & Ascidae & $\mathrm{E}$ & 25 & 4.70 & $\mathrm{w}$ & 27 & 5.63 & $\mathrm{w}$ \\
\hline & ARANEAE & Araneomorphae & $\mathrm{E}$ & 2 & 0.38 & $\mathrm{y}$ & - & - & - \\
\hline COLLEMBOLA & COLLEMBOLA & Collembola & $\mathrm{F}$ & 22 & 4.14 & $\mathrm{w}$ & 1 & 0.21 & $\mathrm{z}$ \\
\hline DIPLODA & SCOLOPENDROMORPHA & Scolopendridae & $\mathrm{E}$ & 2 & 0.38 & $\mathrm{y}$ & - & - & - \\
\hline \multirow[t]{20}{*}{ INSECTA } & COLEOPTERA & Chrysomelidae & $\mathrm{F}$ & 1 & 0.19 & $\mathrm{z}$ & 2 & 0.42 & $\mathrm{y}$ \\
\hline & DIPTERA & Sciaridae & $\mathrm{F}$ & 199 & 37.40 & $\mathrm{w}$ & 222 & 46.26 & $\mathrm{w}$ \\
\hline & & Muscidae & $\mathrm{F}$ & 143 & 26.89 & $\mathrm{w}$ & 71 & 14.80 & w \\
\hline & & Ephydridae & $\mathrm{F}$ & 83 & 15.60 & $\mathrm{w}$ & 97 & 20.21 & $\mathrm{w}$ \\
\hline & & Chloropidae & $\mathrm{O}$ & 6 & 1.13 & $\mathrm{y}$ & 5 & 1.04 & $\mathrm{y}$ \\
\hline & & Agromyzidae & $\mathrm{F}$ & 4 & 0.75 & $\mathrm{y}$ & 3 & 0.63 & y \\
\hline & & Chironomidae & $\mathrm{O}$ & - & - & - & 2 & 0.42 & $\mathrm{y}$ \\
\hline & & Simulidae & $\mathrm{O}$ & - & - & - & 1 & 0.21 & z \\
\hline & & Culicidae & $\mathrm{O}$ & - & - & - & 1 & 0.21 & $\mathrm{z}$ \\
\hline & & Psychodidae & $\mathrm{O}$ & 1 & 0.19 & $\mathrm{z}$ & - & - & - \\
\hline & HEMIPTERA & Aphididae & $\mathrm{F}$ & 5 & 0.94 & $\mathrm{w}$ & 2 & 0.42 & y \\
\hline & HYMENOPTERA & Figitidae & $\mathrm{E}$ & 13 & 2.45 & $\mathrm{y}$ & 22 & 4.58 & $\mathrm{y}$ \\
\hline & & Braconidae & $\mathrm{E}$ & 4 & 0.75 & $\mathrm{w}$ & 2 & 0.42 & z \\
\hline & & Eulophidae & $\mathrm{E}$ & 5 & 0.94 & $\mathrm{y}$ & - & - & - \\
\hline & & Mymaridae & $\mathrm{E}$ & - & - & - & 3 & 0.63 & $\mathrm{y}$ \\
\hline & & Ceraphronidae & $\mathrm{O}$ & 1 & 0.19 & $\mathrm{z}$ & - & - & - \\
\hline & & Formicidae & $\mathrm{E}$ & - & - & - & 1 & 0.21 & $\mathrm{z}$ \\
\hline & LEPIDOPTERA & Heterocera & $\mathrm{F}$ & - & - & - & 1 & 0.21 & $\mathrm{z}$ \\
\hline & THYSANOPTERA & Thripidae & $\mathrm{F}$ & 13 & 2.45 & $\mathrm{w}$ & 15 & 3.13 & w \\
\hline & & Phlaeothripidae & $\mathrm{F}$ & 3 & 0.57 & $\mathrm{y}$ & 2 & 0.42 & y \\
\hline Total & & & & 532 & & & 480 & & \\
\hline
\end{tabular}

* Food habit, F: Phytophagous, E: Entomophages, O: other habits without agricultural interest; N: Number of individuals caught; F: Relative frequency (\%); C: Constancy, w: Constant, y: Accessory, z: Accidental.

Considering all the samples, 1.012 individuals, found in both varieties, the order with the greatest abundance and frequency was Diptera, with 838 individuals captured, which represented $82.81 \%$ of the total arthropods collected between phytophages and entomophages. The second Order in abundance was Araneae with 54 individuals (5.34\%) and the third, Hymenoptera with 51 (5.04\%), which are mostly natural enemies of arthropods. The other orders, together, represented $6.82 \%$ of the total arthropods collected.

The dipterans collected in this study, in both varieties, are mainly from the families Sciaridae, Ephydridae, and Muscidae (Table 4). Sciaridae, which presented the greatest abundance and constancy among dipterans, is considered as an important pest in lisianthus seedlings and whose species may be fusarium vectors (Fusarium avenaceum)
(El-Hamalawi and Stanghellini, 2005). This fly is one of the main pests in protected cultivation systems and nurseries, as adults and larvae can cause direct and indirect damage to the plants, resulting in economic losses (Cloyd, 2015). Leafworms (Agromyzidae), although not as frequent in this survey, are identified as important phytophagous species in different Eustoma species (Nakamura et al., 2013; Weintraub et al. 2017).

The springtails (Collembola) showed the highest frequency in the cultivar Mariage (Table 4), and although no damage to the plants was observed, Alford (2003) reported damage on ornamental plants (cotyledons, hypocotyls, and roots). However, these organisms have been associated with a range of eating habits related to their functional role in the ecological processes that occur in the soil (Fiera, 2009). 
Of the 24 arthropod families collected (Table 4), five were exclusively or predominantly predators (Araneomorphae, Ascidae, Formicidae, Muscidae and Scolopendromorpha) and five were parasitoids (Braconidae, Ceraphronidae, Eulophidae, Figitidae, and Mymaridae) both known as entomophages.

Among the predators, the Muscidae family showed the highest frequency and abundance (Table 4), and represented exclusively by Coenosia sp. This genus is known as a predator of other insects, both in the larval and adult stages (Kühne, 2000). Coenosia species play an important role as biocontrol agents with the potential to predate whiteflies (Aleyrodidae), leave-miner flies (Agromyzidae), shore flies (Ephydridae), and fungal flies (Sciaridae) (Kühne, 2000; Couri and Salas, 2010).

Another group of important predators was the acarids, represented exclusively by the Ascidae (Table 4). Many of these mites are predators of nematodes and small arthropods, especially in the upper layers of the soil, but also feed on pollen or fungi, or are omnivores (Gerson et al., 2003). Santos et al. (2010), studying mites associated with tropical ornamental plants in the southern coastal region of Bahia, also recorded the presence of mites from this family, and they were considered dominant in the studied cultures. This is the first record of Ascidae in lisianthus in Brazil. Among the parasitoids, the family Figitidae (Hymenoptera: Cynipoidea) was the one with the greatest abundance (Table 4), and species of this family have been recorded parasitizing Ephydridae (Díaz et al., 2009).

Considering the week before sampling, the temperature averages ranged from $20.4 \pm 0.33{ }^{\circ} \mathrm{C}$ to $25.3 \pm 0.65^{\circ} \mathrm{C}$ without differences between the shading meshes $(\mathrm{F}=$ $0.9549, \mathrm{p}>0.5)$. There was no significant correlation between the average recorded temperature and the average incidence of arthropods $\left(\mathrm{R}^{2}=0.002, \mathrm{p}=0.9337\right)$. Similarly, the RU (average $65,3 \% \pm 4,5 \%$ ) did not correlate with the density of arthropods captured $\left(\mathrm{R}^{2}=0.1143, \mathrm{p}=0.5122\right)$. According to Rodrigues (2004), these variables may have been responsible for the highest number of insects collected, since temperatures between 15 and $38{ }^{\circ} \mathrm{C}$ correspond to the ideal temperature for the development of most insects, however this cannot be verified in this experiment. In the vegetative phase, the higher soil moisture favored the development of the dipteran population while in the reproductive phase the thrips population was higher.

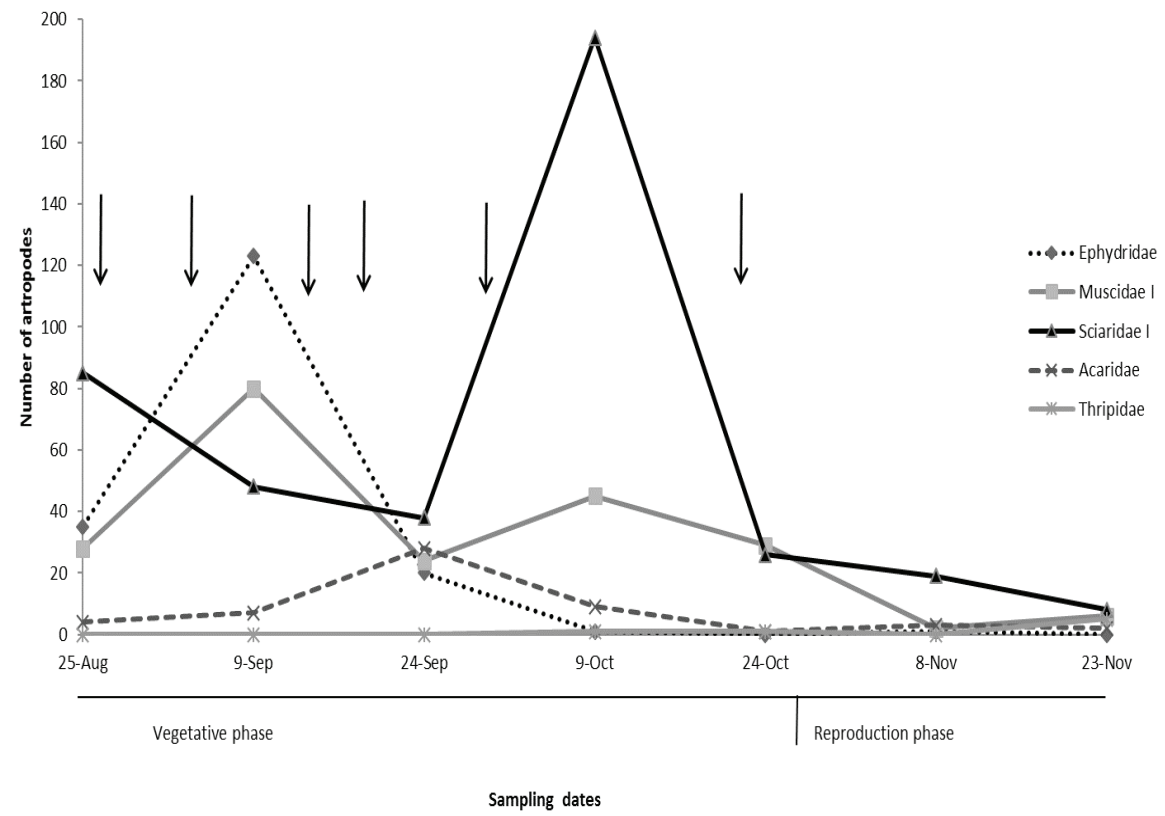

Figure 1. Fluctuation of the density of the most abundant Families collected in greenhouse lisianthus cultivation, from August to November 2012. The arrows indicate the applications of agrochemicals.

The low number of arthropods collected on September 24 (Figure 1) was possibly due to the application of insecticide (cyromazine and spinosad) and fungicide (azoxystrobin + diphenoconazole) on the day before sampling, unlike the other collections when agrochemicals were applied in weeks alternate to collections. The density of thrips, although lower than the others, did not undergo major alterations like the species of other families after the application of insecticides. This may be due to the resistance of thrips to various insecticides, such as cypermethrin (Aizawa et al., 2018). It is also interesting to note that, at that time, the number of acarids (Ascidae) was higher than the other samples, and could be related to the treatment performed, which did not include acaricides. 


\section{Conclusions}

The cultivars under the red mesh obtained the best results and the under the blue, the worst, in general. Nine Orders of arthropods from 24 Families with different habits were recorded, with Diptera being the most abundant. Among the arthropods collected, some species were pests and others may be used for biological control. Shading meshes did not influence the average number of arthropods in plants.

\section{Author Contribution}

M.Y. ${ }^{0000-0002-3937-016 x}$ : Responsible for the implementation, conduction, evaluation of the experiment and writing of the article; S.M.J. ${ }^{0000-0002-0731-5000}$ : Advisor, participating in the design and planning of the experiment and in the correction of the article. G.S. ${ }^{0000-0003-1422-5051}$ : Co-advisor, participating in the design and planning of the experiment and in the correction of the article.

\section{Acknowledgments}

The authors thank to CNPq and FAPERGS for the financial support.

\section{REFERENCES}

AGROFIT. Sistemas de Agrotóxicos Fitossanitários. 2018. Available in: <http://extranet.agricultura.gov.br/ agrofit_cons/principal_agrofit_cons $>$. Accessed on: Apr 01,2018 .

AIZAWA, M.; NAKAI, K.; WATANABE, T.; KUMANO, A.; TAMAGAKI, K.; SONODA, S. A simple method of monitoring for cypermethrin resistance in Thrips tabaci (Thysanoptera: Thripidae) using agar-coated glass pipettes. Applied Entomology and Zoology, v.53, n.1, p.165-170, 2018. DOI:10.1007/s13355-017-0541-9.

ALFORD, D.V. A color atlas of pests of ornamental trees, shrubs and flowers. Portland: Timber Press, 2003. $448 \mathrm{p}$.

ALVES, C.M.; BARBOSA, J.G.; SÁ, P.G.; FINGER, F.L.; GROSSI, J.A.S.; MUNIZ, M.A.; CECON, P.R. Efficiency of preservative solutions on the postharvest life/longevity of lisianthus flowers 'ABC'. Acta Horticulturae, v.1060, p.275-280, 2015. DOI: 10.17660/ActaHortic.2015.1060.41

BACKES, F.; BARBOSA J.G.; BACKES, R.L.; RIBEIRO, J.M.O.; FINGER, F.L.; BARBOSA, M.S. Cultivo de lisianto para flor-de-corte sob diferentes tipos de poda. Bioscience Journal, v.24, n.3, p.60-65, 2008.

CAMARGO, M.S.; SHIMIZU, L.K.; SAITO, M.A.; KAMEOKA, C.H.; MELLO, S.C.; CARMELLO, Q.A.C. Crescimento e absorção de nutrientes pelo lisianthus (Eustoma grandiflorum) cultivado em solo. Horticultura Brasileira, v.22, p.143-146, 2004. DOI:10.1590/S010205362004000100030
CLOYD, R.A. Ecology of Fungus Gnats (Bradysia spp.) in Greenhouse Production Systems Associated with Disease-Interactions and Alternative Management Strategies. Insects, v.6, p.325-332, 2015. DOI: 10.3390/ insects6020325

COOPERATIVA VEILING HOLAMBRA. Critério de classificação lisianthus corte. 4p. 2012. Available in: $<$ http://www.veiling.com.br/qualidade. swf?fileName= Lisianthus\%20 Corte.swf>. Accessed on: Dec 12, 2012.

COURI, M.S.; SALAS, C. First record of Coenosia attenuata Stein (Diptera, Muscidae) from Chile, with biological notes. Revista Brasileira de Entomologia, v.54, n.1, p.144-145, 2010. DOI: 10.1590/S008556262010000100020

DÍAZ, N.B.; GALLARDO, F.E.; GADDI, A.L.; WALSH, G.C. Description of a new genus and species of Eucoilinae (Hymenoptera: Cynipoidea: Figitidae) parasitoid of Ephydridae (Diptera). Annals of the Entomological Society of America, v.102, n.4, p.603-607, 2009. DOI: 10.1603/008.102.0404

DUVAL, C.M. The flower production and family farming. Horticultura Brasileira, v.32, n.2, p.241-241, 2014. DOI: 10.1590/S0102-05362014000200022.

EL-HAMALAWI, Z.A.; STANGHELLINI, M.E. Disease Development on Lisianthus following aerial transmission of Fusarium avenaceum by adult shore flies, fungus gnats, and moth flies. Plant Disease, v.89, n.6, p.619-623, 2005. DOI:10.1094/PD-89-0619

FIERA, C. Biodiversidade de Collembola em solos urbanos e o seu uso como bioindicadores de poluição. Pesquisa Agropecuária Brasileira, v.44, n.8, p.868-873, 2009.

FRANK, T.; AESCHBACHERA, S.; ZALLER, J.G. Habitat age affects beetle diversity in wildflower areas. Agriculture, Ecosystems and Environment, v.152, p.2126, 2012.

GERSON, U.; SMILEY, R.L.; OCHOA, R. Mites (Acari) for pest control. Oxford: Blackwell, 2003. 539p.

HARBAUGH, B.K. Flowering of Eustoma grandiflorum (Raf.) Shinn. cultivars influenced by photoperiod and temperature. Hortscience, v.30, n.7, p.1375-1377, 1995.

HARPAZ, I. Non pesticidal control of vector-borne viruses. In: Harris, K.F.; Maramorosch, K. Pathogens, Vectors, and Plant Diseases. New York: Academic Press, 1982. p.1-21.

HELSON, V.A. Comparison of gro-lux and cool white fluorescent lamps with and without incandescent as light sources used in growth rooms for growth and development of tomato plants. Canadian Journal of Plant Science, v.45, p.416-466, 1965. 
JUNQUEIRA A.H.; PEETZ, M.S. Mercado interno para os produtos da floricultura brasileira: características, tendências e importância socioeconômica recente. Revista Brasileira de Horticultura Ornamental, v.14, n.1, p.3752, 2008. DOI:10.14295/rbho.v14i1.230

KASPERBAUER M.J. Light and plant development. In: Wilkinson R.E. Plant-environment interactions. New York: Marcel Dekker Inc., 1994. p.83-123.

KÜHNE, S. Räuberische fliegen der Gattung Coenosia Meigen, 1826(Diptera: Muscidae) und die möglichkeitihres einsatzesbei der biologischen schädlingsbekämpfung. Studia Dipterologica, v. 9, 78p., 2000.

MATHIAS, J. Lisianto, a flor de corte que conquistou o brasileiro. 2011. Available in: <http://revistagloborural. globo.com/Revista/Common/0,EMI262 864-18293,00LIS $\mathrm{IANTO}+\mathrm{A}+\mathrm{FLOR}+\mathrm{DE}+\mathrm{CORTE}+\mathrm{QUE}+\mathrm{CONQUISTOU}$ $+\mathrm{O}+$ BRASILEIRO.html>. Accessed on: Jun 25, 2012.

McART, S.H.; COOK-PATTON, S.C.; THALER, J.S. Relationships between arthropod richness, evenness, and diversity are altered by complementarity among plant genotypes. Oecologia, v.168, p.1013-1021, 2012. DOI: 10.1007/s00442-011-2150-6

MELO, A.A.M.; ALVARENGA, A.A.D.E. Sombreamento de plantas de Catharanthus roseus (1.) G. Don 'Pacifica White' por malhas coloridas: desenvolvimento vegetativo. Ciência e Agrotecnologia, v.33, n.2, p.514-520, 2009. DOI:10.1590/S1413-70542009000200024

MIYOSHI \& CO., LTD. Catálogo 2012 de flores Miyoshi. Yatsugatake Sales \& Production Center. 2012. Available in: <https://www.miyosi.co.jp/en/e-catalogue/download/> Accessed on: Oct $02^{\text {th }} 2019$.

MURATA, T.; KADOTA, A.; WADA, M. Effects of blue light on cell elongation and microtubule orientation in dark-grown gametophytes of Ceratopteris richardii [Pteridophyta]. Plant and Cell Physiology, v.38, n.2, p.201-209, 1997.

NAKAMURA, S.; MASUDA, T.; MOCHIZUKI, A.; KONISHI, K.; TOKUMARU, S.; UENO, K.; YAMAGUCHI, T. Primer design for identifying economically important Liriomyza species (Diptera: Agromyzidae) by multiplex PCR. Molecular Ecology Resources, v.13, p.96-102, 2013. DOI: 10.1111/17550998.12025 .
OVADIA, R.; DORI, I.; NISSIM-LEVI, A.; SHAHAK, Y.; OREN-SHAMIR, M. Coloured shade-nets influence stem length, time flower, flower number and inflorescence diameter in four ornamental cut-flower crops. Journal of Horticultural Science and Biotechnology, v.84, p.161166, 2009. DOI:10.1080/14620316.2009.11512498.

RODRIGUES, W.C. 2004. Fatores que influenciam no desenvolvimento dos insetos. Info Insetos [On-line], v.1. n.4, p. 1-4. Available in: <http://www.infoinsetos.ebras.bio. br/pdf/art010 4-01.pdf>. Accessed on: Jan 25, 2015.

RONI, M.Z.K.; ISLAM, M.S.; SHIMASAKI, K. Response of Eustoma Leaf Phenotype and Photosynthetic Performance to LED Light Quality. Horticulturae, v.3, n.4, p.1-16, 2017. DOI:10.3390/horticulturae3040050.

SANTOS, R.M.V.; NORONHA, A.C.S.; OLIVEIRA, A.R.; BITTENCOURT, M.A. L. Ácaros (Arachnida: Acari) associados a plantas ornamentais tropicais na região Litoral Sul da Bahia. Arquivos do Instituto Biológico, v.77, n.1, p.43-48, 2010.

SHAHAK, Y.; GAL, E.; OFFIR, Y.; BEN-YAKIR, D. Photoselective shade netting integrated with greenhouse technologies for improved performance of vegetable and ornamental crops. Acta Horticulturae, v.797, p.75-80. 2008. DOI:10.17660/ActaHortic.2008.797.8

SILVA, F.A.S.; AZEVEDO, C.A.V. The Assistat software version 7.7 and its use in the analysis of experimental data. African Journal of Agricultural Research, v.11, n.39, p.3733-3740, 2016. DOI: 10.5897/AJAR2016.11522.

SOTOMAYOR L.E.M.; ROSAS GUERRA, C.A.; MAZUELA, P. Propagación vegetativa de Lisianthus (Eustoma grandiflorum RAF) cv. Abc 2-3 Blue Rim. Idesia, v.34, n.5, p.71-73, 2016. DOI:10.4067/S071834292016005000030

WEINTRAUB, P.G.; SCHEFFER, S.J.; VISSER, D.; VALLADARES, D.; CORREA, A.S; SHEPARD, B.M.; RAUF, A.; MURPHY, S.T.; MUJICA, N.; MACVEAN, C.; KROSCHEL, J.; KISHINEVSKY, M.; JOSHI, R.C.; JOHANSEN, N.S.; HALLETT, R. H.; CIVELEK, H.S.; CHEN, B.; METZLER, H.B. The invasive Liriomyza huidobrensis (Diptera: Agromyzidae): understanding its pest status and management globally. Journal of Insect Science, v.17, n.1, p.1-27, 2017. DOI:10.1093/jisesa/ iew121 